\title{
COSTOS SOCIALES DE LAS REFORMAS NEOLIBERALES EN AMÉRICA LATINA
}

De Anita Kon, Catalina Banko, Dorothea Melcher e Maria Cristina Cacciamali (Coords.)

Caracas : PUC/USP/UCV, 2000. 392 p.

Por Carlos Eduardo Carvalho, Economista e Professor da Pontifícia Universidade Católica de São Paulo.

E-mail: cecarv@uol.com.br

É pouco alentador o balanço social da América Latina, passados mais de dez anos da adesão da maior parte dos países às reformas econômicas liberalizantes. Não há sinais de que estejam sendo equacionados os velhos problemas de marginalização, desigualdade acentuada e exclusão social, e surgiram outras mazelas, como os efeitos das novas tendências de informalização das relações de trabalho e de precarização dos empregos e ocupações, além das restrições aos gastos sociais trazidas pelos programas de "ajuste" fiscal e pelos custos do endividamento crescente do setor público.

As relações entre esse balanço negativo e a natureza das políticas em curso têm sido objeto de estudo e polêmica há alguns anos. Os defensores das reformas alegam que os resultados perversos originam-se da aplicação insuficiente do receituário, fruto da resistência dos

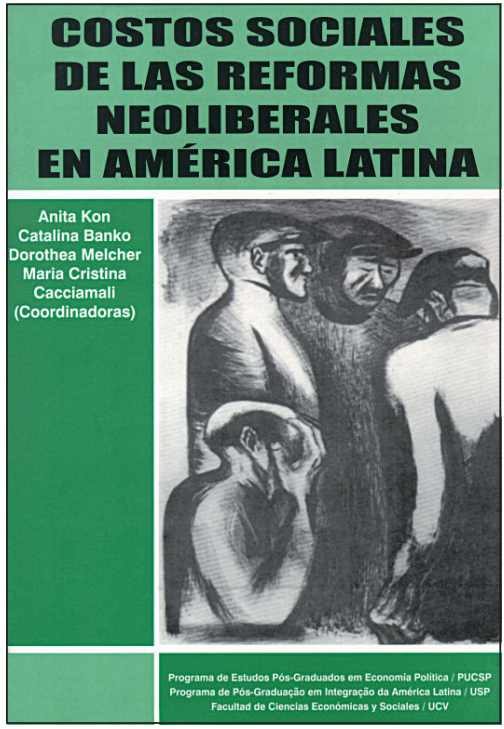

prejudicados e do "atraso" das forças políticas e sociais do continente. Os críticos, ao contrário, apontam que os problemas decorrem da natureza mesma das reformas e que é impossível evitá-los sem ampla reorientação da política econômica. Além da retórica apaixonada, os dois lados têm desenvolvido um número crescente de pesquisas e análises para reforçar seus pontos de vista.

Surge assim, em boa hora, essa coletânea de artigos sobre os custos sociais das reformas, apresentados no simpósio de mesmo título no $50^{\circ}$ Congresso Internacional de Americanistas, em Varsóvia, de 10 a 14 de julho de 2000, em uma edição conjunta da Pontifícia Universidade Católica de São Paulo/Programa de Estudos PósGraduados em Economia Política/Núcleo de Pesquisas em Economia Industrial, Trabalho e Tecnologia, da Universidade de São Paulo/Programa de Pós-Graduação em Integração da América Latina e da Universidade Cen- 
tral de Venezuela/Facultad de Ciencias Económicas y Sociales. São 27 trabalhos reunidos em 392 páginas, de autoria de 31 professores vinculados a universidades e instituições de pesquisa de sete países - dez da Venezuela, sete da Argentina, sete do Brasil, quatro do México, além de um da Colômbia, um da França e um da Ucrânia. Predominam os artigos inspirados por posições críticas diante do modelo econômico atual e muitos alinham-se às teses da inevitabilidade de seus efeitos maléficos.

Há análises gerais sobre as reformas na América Latina e outras focadas em algumas das áreas mais sensíveis das políticas públicas. Os problemas das áreas de saúde, seguridade social, educação e política de alimentação são ressaltados em cinco trabalhos que discutem casos específicos da Venezuela, Colômbia e México. As questões ligadas ao trabalho reúnem quase uma dezena de estudos, destacando os três países citados mais o Brasil e a Argentina. O texto de Cacciamali, por exemplo, aponta o crescimento da informalidade em praticamente todos os países da região na primeira metade dos anos 90 , tendo, em apenas um terço deles, crescido também o emprego formal. Kon salienta os impactos negativos gerais, com o aumento do desemprego e da incompatibilidade da qualificação dos trabalhadores para a modernização das atividades produtivas, mas chama a atenção para o peso de fatores nacionais que condicionam o alcance desses problemas, como as respostas dos governos e a situação prévia de cada país em termos macroeconômicos.

A questão da resposta uniforme ou diferenciada às políticas liberalizantes, aliás, é de grande relevo para o debate latino-americano. Dois trabalhos estudam casos bem delimitados, o de Campanhol, sobre a região de Franca, no estado de São Paulo, no Brasil, e o de López, sobre a região centro-ocidental da Venezuela.

A viabilização política das reformas aparece em alguns estudos sobre a área de trabalho e emprego. $\mathrm{O}$ trabalho de Melcher destaca a baixa resistência da população e dos dirigentes sociais e políticos da Venezuela às reformas e procura identificar elementos da cultura política que podem ter facilitado esse desfecho. Muito interessante é a pesquisa de Bonetto e Piñero a respeito do discurso sobre o trabalho e o movimento operário nas principais forças políticas argentinas. $\mathrm{O}$ artigo de Palermo analisa a dinâmica política que acompanhou a forte mudança na política econômica daquele país. Outro texto muito interessante é o de Delgado, que aborda as relações entre as Forças Armadas da região e o modelo liberalizante, ressaltando a relativa saída de cena desse protagonista decisivo na política de nossos países nas décadas anteriores.
Um outro corte analítico sobre a gênese e a viabilização das reformas liberalizantes aparece no estudo de Banko sobre os contrastes e as convergências nas trajetórias de Argentina e Venezuela. Apesar das substanciais diferenças do quadro econômico e das opções políticas nas décadas anteriores, os dois países foram igualmente "capturados" pelo circuito financeiro internacional e arrastados para a crise da dívida de vinte anos atrás. $\mathrm{O}$ artigo de Marques-Pereira aponta uma linha explicativa ao enfatizar o peso dos fatores financeiros e monetários na inserção dependente de nossos países ao sistema econômico internacional.

O debate sobre a prevalência dos fatores internos ou externos para explicar os efeitos das reformas é tema de outros trabalhos da coletânea, como Abreu e Di Marco. A complexidade do tema é salientada na análise específica de Gastaldi, Rio e Buchieri com relação aos impactos da desvalorização cambial brasileira de janeiro de 1999 sobre a economia argentina. Os autores defendem o regime de conversibilidade e atribuem às turbulências financeiras internacionais a principal responsabilidade pelos problemas recentes no país platino.

O artigo de Kanov analisa as motivações e a ideologia que orientaram a privatização no México e conclui que não se materializaram seus alegados benefícios sociais, o que reforça a conclusão da maioria dos textos da coletânea sobre a necessidade de políticas direcionadas para enfrentar os problemas sociais. López discute o desenho das políticas sociais e da intervenção estatal como programas "universais" ou "locais". O debate dessas opções é da maior importância para a redefinição das políticas e das propostas da oposição em vários países. Os defensores do modelo liberalizante no Brasil pregam o fim de todas as políticas "focadas", ou específicas, definidas como espaços de ineficiência e corrupção, com o que justificaram a desmontagem de vários programas sociais bem-sucedidos.

Muitos outros trabalhos merecem comentário, mas é impossível fazê-lo nos limites de uma resenha, dada a amplitude dos temas cobertos. Essa diversidade é um dos méritos da coletânea e torna-a interessante não apenas para economistas ligados aos temas sociais e à macroeconomia mas também para profissionais e estudiosos de áreas diversas. Pela destinação ao público mais amplo, teria sido interessante incluir em todos os textos uma pequena introdução e um resumo das conclusões, além de uma introdução geral ao volume que apresentasse um painel das questões para o leitor. São pequenos reparos, que em nada diminuem a importância da obra. $\bigcirc$ 